\title{
TEMPOROMANDIBULAR JOINT DYSFUNCTION AND TRAPEZIUS MUSCLE FATIGABILITY
}

\author{
Ritzel CH, Diefenthaeler F, Rodrigues AM, Guimarães ACS e Vaz MA \\ Escola de Educação Física, Universidade Federal do Rio Grande do Sul, Porto Alegre, RS - Brasil \\ Correpondência para: Marco Aurélio Vaz, Laboratório de Pesquisa do Exercício, Universidade Federal do Rio \\ Grande do Sul, Rua Felizardo, 750, CEP 90690-200, Porto Alegre, RS - Brasil, e-mail: ciritzel@terra.com.br; \\ marcovaz@esef.ufrgs.br
}

Recebido: 25/05/2006 - Revisado: 06/12/2006 - Aceito: 30/07/2007

\begin{abstract}
Introduction: It has been suggested that pain increases trapezius muscle activation in patients with temporomandibular joint dysfunction (TMD). Changes in muscle activation might change muscle resistance to fatigue. The purpose of this study was to evaluate the fatigability of the trapezius muscle in patients with TMD. Method: Fourteen patients with TMD (clinically diagnosed and referred by a dentist) and eleven healthy subjects performed a fatigue test consisting of shoulder elevation performed at $70 \%$ of the maximal voluntary isometric contraction, which was maintained for 30 seconds. Electromyographic signals were obtained from the upper portion of the trapezius muscle (sampling frequency: $2000 \mathrm{~Hz} / \mathrm{channel).} \mathrm{Consecutive} \mathrm{segments} \mathrm{of} \mathrm{three} \mathrm{seconds} \mathrm{in} \mathrm{duration} \mathrm{each}$ were extracted from the electromyographic signal and analyzed in the frequency domain using a Fast Fourier Transform algorithm. Linear regression analysis was applied to the consecutive median frequencies for each subject. The slope of the regression line was used to describe muscle fatigability. Results: No changes were observed in fatigability between the right and left trapezius of either group or between the left trapezius of the healthy and TMD groups. The linear regression for median frequencies in the right trapezius of the TMD group showed a slope of $-0.15 \pm 0.33$ (mean \pm SD), which was smaller than the slope for the healthy group $(-0.44 \pm 0.46 ; \mathrm{p}=0.049)$. These results suggested that the fatigability of the right trapezius was lower in the TMD group than in the healthy group.
\end{abstract}

Key words: temporomandibular joint dysfunction; trapezius muscle; median frequency; EMG; fatigue.

\section{RESUMO}

\section{Disfunção Temporomandibular e a fatigabilidade do músculo trapézio}

Introdução: Tem sido sugerido que a dor aumenta a ativação do músculo trapézio em pacientes com disfunção temporomandibular (TMD). Mudanças na ativação do músculo podem alterar a resistência à fadiga. O objetivo do estudo foi investigar a fatigabilidade do músculo trapézio em pacientes com TMJ. Método: Quatorze indivíduos com TMD (diagnosticados clinicamente e encaminhados pelo especialista odontólogo) e onze indivíduos saudáveis realizaram um protocolo de fadiga que consistiu em uma contração isométrica submáxima de elevação do ombro, em um nível de $70 \%$ da contração voluntária máxima, mantida por um período de 30 segundos. O sinal eletromiográfico (EMG) foi obtido da porção superior do músculo trapézio, (taxa de amostragem de 2000Hz/canal). Três segundos consecutivos do sinal EMG foram analisados no domínio da freqüência usando a Transformada Rápida de Fourier (FFT). Uma análise de regressão linear foi aplicada para valores consecutivos da freqüência mediana (MF) de cada sujeito, e a inclinação da regressão linear foi utilizada para descrever a fatigabilidade muscular. Resultados: Nenhuma diferença foi observada na fatigabilidade do músculo trapézio direito e esquerdo para ambos os grupos e entre o trapézio esquerdo do grupo saudável e com TMD. A MF do músculo trapézio direito do grupo com disfunção apresentou valores de inclinação da reta de regressão linear de $-0,15 \pm 0,33$ (média $\pm \mathrm{SD}$ ), os quais foram menores que os valores do grupo saudável $(-0,44 \pm 0,46$; média $\pm \mathrm{SD}$; $\mathrm{p}=0,049$ ). Esses resultados sugerem que a fatigabilidade do trapézio direito é menor no grupo com TMD do que no grupo saudável.

Palavras-chave: disfunção temporomandibular; músculo trapézio; mediana da freqüência; EMG; fadiga. 


\section{INTRODUCTION}

The etiology of temporomandibular joint dysfunction (TMD) is known to be multifactorial. It may be related to an imbalance between occlusal, anatomical, psychological and neuromuscular factors, thus promoting head and neck structural dysfunction.

The stomatognathic system is a functional unit of the body characterized by several tissues of different origin and structure that act in consonance to perform different functional tasks. It comprises the joint connection between the mandible and the base of the skull, which in turn has muscle and ligament connections to the neck region ${ }^{1}$. It consists of skeletal components (maxilla and mandible), dental arches, soft tissue (salivary glands, nervous and vascular supplies), temporomandibular joints (TMJ) and muscles. These structures are interconnected and interrelated; when activated, they aim to achieve maximal efficiency with protection of all the participating tissues ${ }^{2,3}$.

In evaluating the relationship between the skull and the cervical spine from a sagittal viewpoint, it can be seen that the greatest part of the weight of the skull (its center of gravity) lies on the anterior region of the cervical spine and the TMJ. As a result, its orthostatic position is maintained by a complex muscle mechanism involving the muscles of the head, neck and shoulder girdle. Any change to one of these structures may lead to postural imbalance, not only locally but also in other muscle chains of the organism, because of their close relationships ${ }^{2}$. The complex anatomical and biomechanical interactions between the stomatognathic system and the head and neck area are responsible for the relationship between TMD and posture. Several studies have shown that patients with TMD present changes in their head and shoulder positions, as well as increased cervical lordosis ${ }^{4-6}$.

Shifts in head and shoulder positions can result from a variety of changes, such as foot abnormalities or craniomandibular disorders. Disorders of the stomatognathic system, such as muscle hyperactivity, for example, lead to anterior cervicoscapular displacement ${ }^{2,3,7}$. The increased activity of the masticatory muscles affects the muscles responsible for countersupport (sternocleidomastoid and trapezius muscles), thus resulting in shortening of the posterior muscles of the neck and lengthening of the anterior muscles, with anterior projection of the body ${ }^{2}$. Anterior positioning of the head will simultaneously lead to disorders of mandibular positioning and functioning, thus resulting in increasing tension in the masticatory muscles and, as a result, $\mathrm{TMD}^{8-10}$

Other authors have stated that, since masticatory and cervical muscles are synergic, an imbalance between them gives rise to different forces acting on the mandible. These lead to changes in muscle resting positions and muscle hyperactivity ${ }^{11}$.
Shoulder positioning can also be altered by increased masticatory muscle activity ${ }^{12-14}$. Lack of shoulder leveling ${ }^{12-14}$ may be present, with protrusion or elevation of the shoulder on the same side as the affected TMJ. Changes in shoulder position could develop because the masticatory muscle hyperactivity leads to cervical muscle hyperactivity, with contraction of the muscles responsible for shoulder elevation and protrusion ${ }^{7}$. In contrast, other authors have not found any significant relationship between lack of shoulder leveling and muscle activity ${ }^{15}$.

These changes in load pattern may produce temporary as well as permanent changes in the reciprocal positions of pairs of articulating joint surfaces. Up to a certain point, these changes may be compensated by adaptive mechanisms of the musculoskeletal tissues, which may in turn lead to joint and/or muscle injuries ${ }^{11,12}$. Therefore, abnormal positioning of the head changes the biomechanics of the craniocervical and craniomandibular relationships, in the same way as abnormal mandibular positioning leads to changes in the craniocervical relationship ${ }^{2}$.

During mastication, the rhythmic sequence of the dynamic contractions and relaxations enables sufficient level of blood flow to supply the TMJ muscles. Joint locking and tooth wear may occur at the TMJ, thereby changing the masticatory function ${ }^{3}$. Postural deformities may add to this scenario, through changing the positioning of the hyoid bone, and consequently the mandibular positioning. All these factors may lead to increased activity of the muscles in the head, neck and shoulder, thus changing their resistance to fatigue ${ }^{3}$.

It has been demonstrated that the masseter muscle and the upper portion of the trapezius are a frequent source of pain. This leads to an increase in their fatigability and a reduction in their endurance in response to a given load ${ }^{3,13}$. It has been shown that the most painful body site is the cervical spine, followed by the scapular region and the temporomandibular joint ${ }^{6}$.

The position of the head over the neck determines the posture of the body and is responsible for body balance and head movements. The TMJ is directly related to the cervical and scapular regions by a common neuromuscular system. Changes in the cervical spine may lead to TMJ disorders and vice versa. It has been shown that the number of patients with TMD who also have postural disorders is high ${ }^{7,11,16}$.

One way of analyzing the fatigue caused by TMD is through the electromyographic activity of the muscles involved. Electromyography (EMG) has thus been used not only to diagnose but also to monitor improvement and evaluate the treatment effectiveness ${ }^{17}$. Although EMG is a simple noninvasive technique used to evaluate fatigue, and TMD presents high incidence, we were unable to find any studies evaluating the relationship between trapezius muscle fatigability and TMD. Therefore, the purpose of this study was to evaluate this relationship between trapezius fatigability and TMD. 


\section{MATERIALS AND METHODS}

Fourteen patients with TMD (dysfunction group) and eleven healthy subjects (healthy group) signed an informed consent statement in order to participate in the study, which had been approved by the Ethics Committee of the Clinical Hospital of Porto Alegre (Protocol No. 01-257). Subjects from the dysfunction group were selected following a clinical diagnosis of TMD from a dentist. The criterion for inclusion in the dysfunction group was that subjects should present signs and symptoms of TMD or craniomandibular disorders, malocclusion and masticatory muscle pain. The subjects in the healthy group did not have any musculoskeletal disease or symptoms of TMD.

The fatigability of the left and right trapezius muscles was determined during submaximal isometric contraction of the scapular elevator muscles ${ }^{18}$. A load cell constructed in-house (instrumented with strain gauges), an amplifier (ENTRAN MSC6, with a supply bridge of $1 \mathrm{~V}$ and gain of $1 \mathrm{~K}$ ) and an oscilloscope (Missipa, MO-1221S, $20 \mathrm{MHz}$ ) were used to determine the submaximal level of voluntary effort. Two Velcro straps were used between the subject's shoulder and the load cell, which was fixed to a large metal plate positioned underneath the chair where the subject was seated.

EMG signals were obtained using an eight-channel system (Bortec Electronics Inc., Calgary, Canada) and bipolar surface electrodes (Kendal Meditrace, $\mathrm{Ag} / \mathrm{AgCl}, 2.2 \mathrm{~cm}$ in diameter) that were attached to the skin over the upper portion of the trapezius muscle, in the approximate direction of the muscle fibers. A reference electrode was attached to the skin over the clavicle. Prior to electrode placement, the skin impedance was reduced by means of skin shaving and skin abrasion using a piece of cotton soaked in alcohol ${ }^{19}$. All the procedures for skin preparation and electrode positioning were in accordance with the standards of the International Society of Electromyography and Kinesiology ${ }^{20,21}$.

After amplification, the EMG signals were digitized at a frequency of $2000 \mathrm{~Hz}$ per channel using an analog-todigital board (Dataq Instruments Inc., Akron, USA), and were stored on a Pentium IV computer for further analysis.

The protocol consisted of three maximal isometric voluntary contractions (MIVCs) for scapular elevation (three seconds duration each). From the greatest contraction, the level of $70 \%$ MIVC was calculated and the subjects were asked to maintain this 70\% MIVC for a period of 30 seconds (fatigue test) $)^{22}$. Visual feedback was given through an oscilloscope. One-minute intervals were observed between contractions. The same protocol was used on both sides in order to evaluate possible differences between sides, in both groups.

The EMG signals from the fatigue trials were cut into consecutive three-second segments, thus resulting in ten segments. A bandpass filter (with cutoff frequencies of 10 and $500 \mathrm{~Hz}$ ) was applied to the signals obtained. The median frequencies were calculated using a Fast Fourier Transform algorithm. Linear regression was applied to the ten consecutive median frequencies, and the slope was used to evaluate the fatigue $^{23}$. The slopes were compared between sides (intragroup comparison) using Student's t test for paired samples and between groups (intergroup comparison) using Student's t test for independent samples. The statistical analyses were performed using the Sigma Stat 2.03 software (SPSS Inc.). A significance level of 0.05 was adopted for all tests.

\section{RESULTS}

The slopes of the linear regression lines for the median frequencies from the right and left sides of the healthy group were $-0.44 \pm 0.46$ (mean \pm SD) and $-0.30 \pm 0.30$, respectively (Figure 1A). The slopes of the linear regression lines for the median frequencies from the right and left sides of the TMD group were $-0.15 \pm 0.33$ (mean $\pm \mathrm{SD}$ ) and $-0.23 \pm 0.30$, respectively (Figure 1B). Both groups and both sides showed decreasing median frequency with increasing fatigue. However, there was no difference in the median frequency behavior between the sides in either group ( $p=0.250$ for the healthy group; $\mathrm{p}=0.847$ for the TMD group).

The intergroup comparison revealed different behavior for the right side between the groups ( $\mathrm{p}=0.049$; Figure $2 \mathrm{~A}$ ), such that the healthy group showing a larger decrease in median frequency (bigger slope values) with increasing fatigue, in comparison with the TMD group. No difference between groups was observed for the left side $(p=0.451$; Figure 2B).

\section{DISCUSSION}

The relationships between the head, the cervical region of the spine and the TMJ are usually determined by the functional demands at each joint, and these determine muscle function. TMD is a disease that occurs between the neck, cranium and mandible, and is believed to change muscle function, especially in terms of the fatigability of the muscles. The trapezius muscle, for example, is recruited systematically to produce stability at the neck. This muscle is also activated by pain reflexes as a protective mechanism. This increased recruitment of the trapezius muscle may change its ability to sustain prolonged contractions in patients with TMD, which may lead to significant changes in body posture. These findings, associated with the complex anatomical and biomechanical interaction between the stomatognathic system and the head and neck regions, have led many scientists to discuss these relationships ${ }^{7,11,13,15}$.

It has been shown, for example, that the morphology of the craniofacial skeleton is related to the shape and/or structure of the mandibular muscles, as well as to clinical 

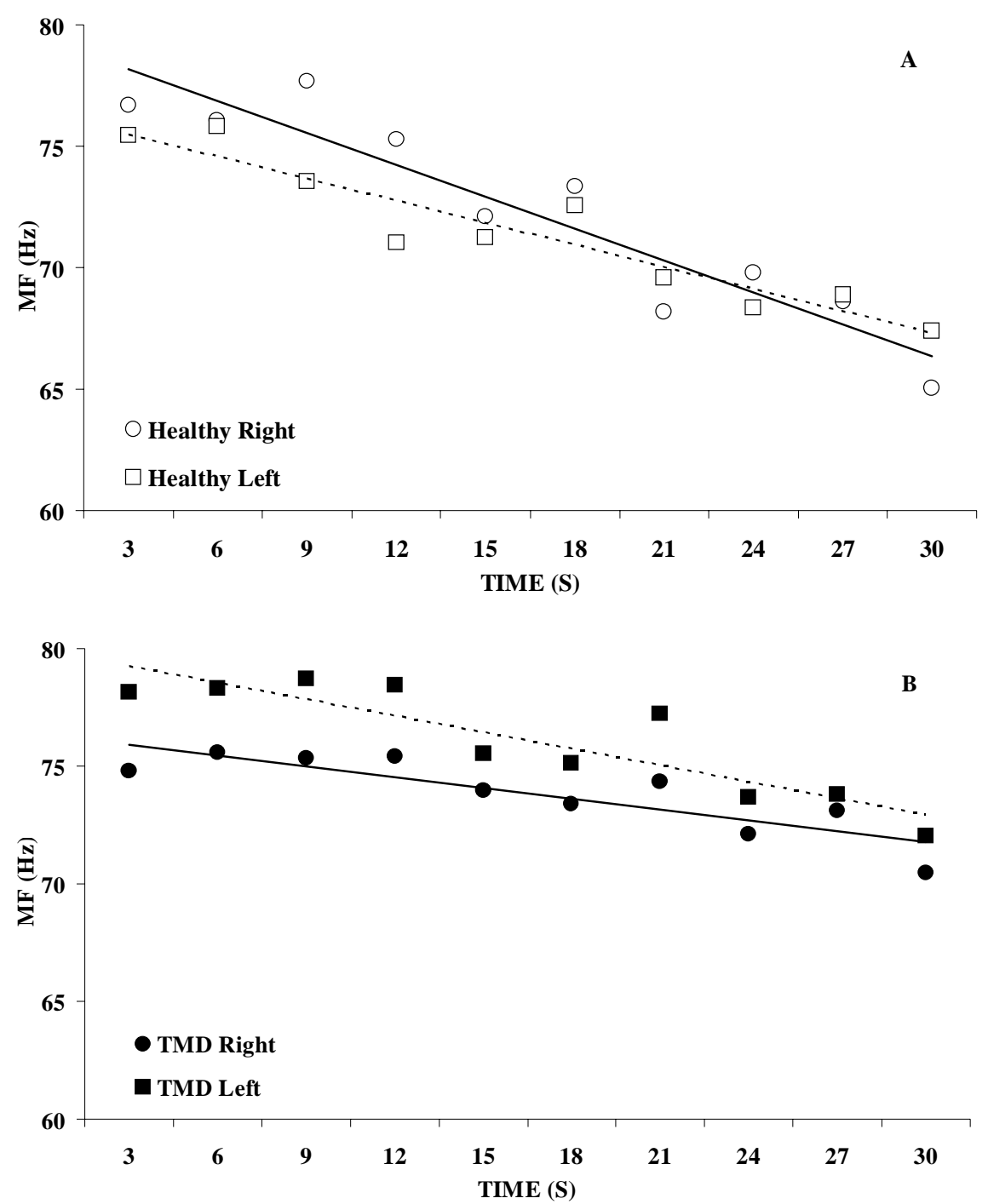

Figure 1. Mean values for the median frequencies of the right and left trapezius muscle of the healthy (A) and TMD (B) groups. The regression lines shown in the figure illustrate the mean behavior of the median frequency on each side and in each group. Mean values and standard deviations were calculated from the slopes obtained from the regression analysis on each subject, and for each side within each group. Healthy group, right side: $r=0.44 \pm 0.46$; left side: $r=-0.30 \pm 0.30$. TMD group, right side: $r=-0.15 \pm 0.33$; left side: $r=-0.23 \pm 0.30$. No differences were observed when comparing the slopes between the sides in either group (healthy group: $\mathrm{p}=0.250$; TMD group: $\mathrm{p}=0.847$ ).

symptoms ${ }^{11}$. The relationships between the muscles of the head, neck and trunk may contribute towards mandibular movements and help to establish the positioning of the mandible ${ }^{24}$. Chronically altered craniocervical posture could lead to mandibular postural changes through biomechanical ${ }^{25}$ and neuromuscular mechanisms ${ }^{26}$. Some authors have reported postural pattern abnormalities in TMD subjects, in comparison with healthy subjects ${ }^{27,28}$, although others ${ }^{16}$ have not found differences between TMD and healthy subjects.

It has been suggested that psychological stress induces changes in biting patterns and the development of tooth grinding, thereby increasing the activity of the mastication muscles. This increased activity of the mastication muscles is one of the causes of myofascial pain, and seems to result in decreased contraction strength and increased fatigue, which might lead to the development of trigger points ${ }^{3}$. A relationship between increased muscle EMG activity in the neck muscles and myofascial pain has been observed in subjects with TMD. This myofascial pain might not be limited just to these neck and masticatory muscles, but might spread out to several body parts, for example to the shoulder region ${ }^{4-6,8-10}$.

The results presented here show that the median frequency of the EMG signal is a good indicator for studying muscle fatigue, since there was a decrease in the median frequency of the trapezius muscle with increasing fatigue on both sides (right and left) of both groups (control and TMD; Figures $1 \mathrm{~A}$ and $1 \mathrm{~B}$ ). The median frequency of the EMG signal has been shown to be strongly associated with 

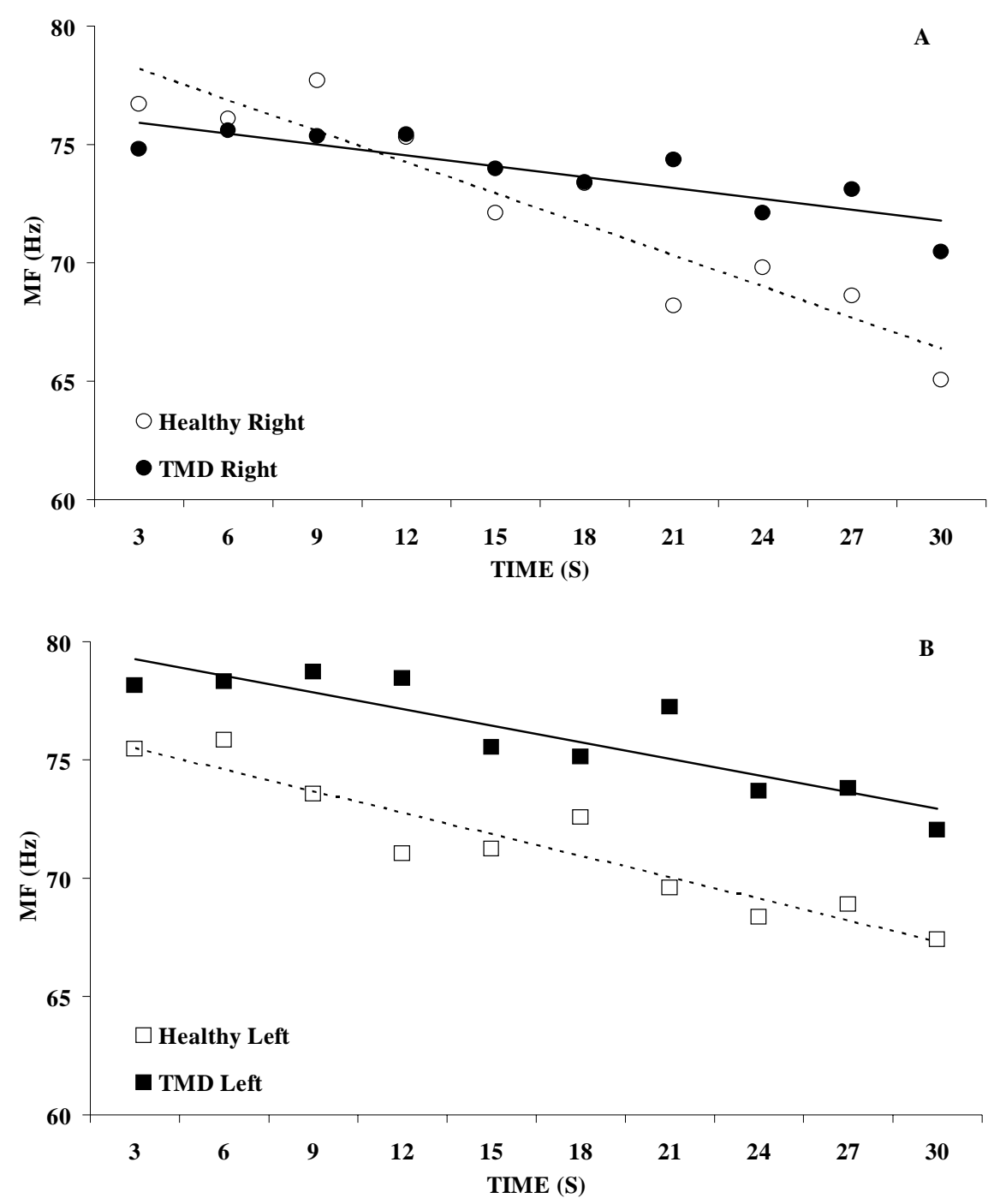

Figure 2. Mean values for the median frequencies of the right (A) and left (B) trapezius muscle of the healthy and TMD groups. The slope values are the same as in Figure 1. There was a difference between the slopes for the right trapezius between the healthy and TMD groups $(p=0.049)$, whereas no difference was observed when comparing the slopes for the left side between the two groups ( $p=0.451)$.

the conduction velocity of the motor action potential ${ }^{10}$. This means that the conduction velocity of the action potential decreases with increasing fatigue bilaterally. This was somehow expected, as TMD usually affects both sides, and therefore there should not be any difference in fatigue in intragroup comparisons. However, we expected that TMD should increase the fatigability of the trapezius muscle, in comparison with the fatigability of the healthy group.

When comparing the sides between the two groups, the right side of the TMD group showed lower fatigability than in the control group (Figure 2A), but this did not occur on the left side (Figure 2B). The lower fatigue on the right side of the TMD group (shown by the smaller slope values) than in the healthy group might be explained by the plasticity of the neuromuscular system. This plasticity has been described as an ability to functionally adapt the neuromuscular system in response to experiences of overload or injury ${ }^{12}$. Such adaptation may result in functional reorganization enabling higher resistance to fatigue by the injured muscle, despite the dysfunctional problem in the neuromuscular and skeletal systems $^{12}$.

Another possible explanation for this decreased fatigability on the right side is that nearby muscles might have been recruited to substitute for the injured or fatigued muscle, in order to give this muscle temporary relief ${ }^{12}$. In this way, the injured muscle may be protected from increased injury by decreasing its level of activation (which could be considered to be a neural adaptation).

Although the median frequency of the EMG signal seems to be a good indicator of fatigue, it appears that it shows a single aspect of fatigue (i.e. the conduction velocity of the motor action potential). Another study ${ }^{22}$ has shown that, one to five minutes after the end of a submaximal (70\% MIVC) isometric fatigue protocol, there was a recovery in the median 
frequency of the EMG signal in the rectus femoris and vastus lateralis muscles. However, these authors stressed the fact that the root mean square (RMS) values of the EMG signal did not recover, even 15 minutes after the recovery in these muscles. This suggests that the conduction velocity of the action potential has a fast recovery, while muscle fatigue still exists. Therefore, looking at more than one fatigue index seems to be important when studying muscle function, since this may reveal different aspects of fatigue.

We have shown that patients with TMD presented lower fatigability of the right trapezius muscle, in comparison with healthy subjects. The reason for this difference is not completely understood. It is possible that these patients had different levels of pain bilaterally, thus leading to differing resistance to fatigue. However, as we did not control for pain, it is difficult to evaluate this possibility. Also, we did not determine whether the patients had different degrees of TMD, and this might be another variable or factor influencing our results. It has been shown that patients with different degrees of TMD show different levels of pain and different joint function ${ }^{26,29}$, which might have affected muscle function and therefore the fatigability of the muscle. The influence of these factors remains to be determined.

Acknowledgments: The authors would like to express their gratitude to Prof. Antônio Carlos Stringhini Guimarães, who tragically passed away in October 2005, for his guidance over many years and for being one of the first scientists to introduce the field of electromyography in Brazil.

\section{REFERENCES}

1. Okenson JP. Etiologia dos distúrbios funcionais do sistema mastigatório. In: Fundamentos de oclusão e desordens temporomandibulares. $2^{\text {a }}$ ed. São Paulo: Arte Médicas; 1992. p. 117-35.

2. Rocabado MS. Cabeza y cuello - Tratamento articular. Buenos Aires: Inter-Médica; 1979.

3. Mongini F. ATM e músculos craniocervicofaciais: Fisiopatologia e tratamento. São Paulo: Santos Editora; 1998.

4. Amantéa DV, Novaes AP, Campolongo GD, Barros TP. The importance of the postural evaluation in patients with temporomandibular joint dysfunction. Acta Ortop Bras. 2004;12(3):155-9.

5. Munhoz WC, Marques AP, Siqueira JTT. Radiographic evaluation of cervical spine of subjectswith temporomandibular joint internal disorder. Braz Oral Res. 2004;18(4):283-9.

6. Pedroni CR, Oliveira AS, Berzin F. Pain characteristics of temporomandibular disorder - a pilot study in patients with cervical spine dysfunction. J Appl Oral Sci. 2006;14(5): 388-92.

7. Mannheimer JS, Rosenthal RM. Acute and chronic postural abnormalities as related to craniofacial pain and temporomandibular disorders. Dent Clin North Am. 1991;35(1):185-209.
8. Ayub E, Glasheen-Wray M, Krauss S. Head posture: a case report of the effects on the rest position of the mandible. J Orthop Sports Phys Ther. 1984;5(4):179-83.

9. Friedman $\mathrm{MH}$, Wusberg I. Screening procedures for temporomandibular joint dysfunction. Am Fam Phys. 1982; 25(6):157-60.

10. Janda V. Some aspects of extracranial causes of facial pain. J Prosthet Dent. 1981;56(4):484-7.

11. Darling DW, Krauss S, Clasheen-Wray MB. Relationship of head posture and the rest position of the mandible. J Prost Dent. 1994;52(1):111-5.

12. Lieber RL. Skeletal muscle structure, function \& plasticity The physiological basis of rehabilitation. $2^{\mathrm{a}}$ ed. Philadelphia: Lippincott Williams \& W. Wilkins; 2002.

13. Clark GT, Green EM, Dornam MR, Flack VF. Craniocervical dysfunction levels in a patient sample from a temporomandibular joint clinic. J Am Dent Assoc. 1987; 115(2):251-6.

14. Fuents R, Freesmeyer W, Henriquez J. Influencia de la postura corporal em la prevalência de las dysfunciones craniomandibulares. Rev Méd Chile. 1999;127:1079-85.

15. Robocado SM, Tapia V. Radiographic study of craniocervical relation in patients under orthopedic treatment and the incidence of related symptom. J Craniomandib Pract. 1987;5:13-7.

16. Zonnemberg AJJ, Van MAAnem CJ, Oostendorp RAB, Elvers JWH. Body posture photographs as a diagnostic aid for musculoskeletal disorders related to temporomandibular disorders. J Craniomandib Pract. 1996;14(3):225-32.

17. De Luca JC. Use of the surface EMG signal for performance evaluation of back muscles. Muscle \& Nerve. 1993;16:210-6.

18. De Luca JC. Myoeletric manifestation of localized muscular fatigue in humans. Crit Rev Biomed Eng. 1989;2(4):251-79.

19. Solderberg GL, Knuston L. A guide for use and interpretation of kinesiologic electromyographic data. Phys Ther. 2000; 8(5):485-98.

20. Merletti R. Standards for reporting EMG data. J Electromyogr Kinesiol. 1997;7(4):1-2.

21. Hermes, HJ. Recommendations for sensor locations in shoulder or neck muscles [homepage na internet]. Netherlands: Seniam Project; [atualizada em 27 Ago 2007; acesso em 30 Mar 2006]. Disponível em: http://www.seniam.org/.

22. Vaz MA, Zhang YT, Herzog W, Guimarães ACS, Macintosh BR. The behavior rectus femoris and vastus lateralis during fatigue and recovery. Electrom Clin Neurophysiol. 1996; 36:221-30.

23. Candotti CT, Castro FAS, Scheeren EM, Pressi AMS, Loss JF, Vaz MA, et al. EMG signal behavior in human vastus lateralis, tibialis, tibialis anterior and soleus muscles during fatigue. Braz J Biomech. 2004;9:15-9.

24. Jiang T, Yang Z, Zhang Z, Feng H. Electromyography activities of head, neck and upper trunk muscles with mandibular movement in normal adults. J Zhonghua Hou Qiang Yi Xue Za Zhi. 2002;37(6):431-4. 
25. Funakoshi M, Fujita N, Takehana S. Relations between occlusal interference and jaw muscle activities in response to changes in head position. J Dent Res. 1976;55:68-72.

26. Gonzalez HE, Manns A. Forward head posture: its structural and functional influence on the stomatognathic system. A conceptual study. Cranio. 1996;14:71-80.

27. Huggare JA, Raustia AM. Head posture and cervicovertebral and craniofacial morphology in patients with craniomandibular dysfunction. Cranio. 1992;10:173-9.
28. Lee WY, Okeson JP, Lindroth J. The relationship between forward head posture and temporomandibular disorders. J Orofac Pain. 1995;9:161-7.

29. Teixeira ACB, Marcucci G, Luiz JGC. Prevalência das maloclusões e dos índices anamnésicos e clínicos em pacientes com disfunção da articulação temporomandibular. Rev Odontol Univ São Paulo. 1999;13(3):251-6. 